腎細胞癌の病理組織学的検討

一核型による悪性度と予後について一

\begin{tabular}{|c|c|c|c|c|}
\hline \multirow{4}{*}{ 北海道大学医学部泌尿器科 } & $\begin{array}{l}\text { 中 } \\
\text { 柏 }\end{array}$ & 西 & - & 郎 \\
\hline & 坂 & 下 & 茂 & \\
\hline & 丸 & \multicolumn{3}{|c|}{ 彰 } \\
\hline & 小 & 柳 & 知 & \\
\hline \multirow{4}{*}{ 市立小樽病院泌尿器科 } & 有 & 門 & 克 & \\
\hline & 森 & \multicolumn{3}{|c|}{ 達 } \\
\hline & 川 & 倉 & 宏 & \\
\hline & 大 & 橋 & 伸 & \\
\hline \multirow[t]{2}{*}{ 市立札幌病院泌尿器科 } & 山 & 田 & 智 & \\
\hline & 斯 & 波 & 光 & \\
\hline
\end{tabular}

\title{
PATHOLOGICAL STUDY OF RENAL CELL CARCINOMA
}

-Significance of Nuclear Morphologic Grade in Prognosis-

Shoichiro Nakanishi, Akira Kashiwagi, Shigeo Sakashita, Akio Maru and Tomohiko Koyanagi

Department of Urology, Hokkaido University School of Medicine

Katsuhisa Arikado, Tatsuya Mori and Koichi Kawakura

Department of Urology, Otaru City Hospital

Nobuo Oohashi, Tomoji Yamada and Teruo Shiba

Department of Urology, Sapporo City Hospital

A clinico-pathological study was performed in 154 patients with renal cell carcinoma experienced during the 14-year-period from 1969-1982.

The prognosis was correlated with the clinical stage based on Robson's classification and in particular with pathological features such as cell type, structural pattern and nuclear morphologic grade (NMG) as well. By modifying Skinner's grading system, NMG was divided into four subgroups (grade 1 to 4 ) depending on the differences in nuclear size, oral shape, irregularity, chromatin pattern and nucleoli prominence.

Results:

1) The 5-year survival rates were $68.0 \%, 64.9 \%, 34.9 \%$ and $6.2 \%$ for stages I, II, III and IV, respectively. The survival rates and stages were significantly correlated as a whole but the difference between stage I and II was not statistically significant.

2) Neither cell type nor structural pattern has no relevance to survival, while mixture of spindle cell and sarcomatoid pattern was definitely a poor prognostic sign.

3) The 5-year survival rates were $80.4 \%, 71.5 \%, 33.1 \%$ and $7.9 \%$ for grades $1,2,3$ and 4 , respectively. As with the stages, there was a significant correlation between the survival rates and grade, although simplified classification by high grade ( 3 and 4 ) and low (grade 1 and 2 ) system is also indicative of poor and favorable prognosis, respectively.

4) Stages and grades were correlated well in such a way that lower stage tumors were comprised 
mainly of lower grade ones and vice versa. Although both are of prognostic value in assessing the patients as a group, grades were more indicative of individual prognosis, since death with low stage tumors was found only in patients with high grade tumors and most long term survivors with high stage tumor demonstrated low grade tumor.

5) MNG was more valuable than the other pathological findings in predicting the subsequent course of patints following nephrectomy, when combined with clinical stage.

要旨：1969年から1982年までの14年間の追跡可能であった腎細胞癌症例153例（男110，女43）を対象と 乙臨床病期（stage）および病理組織学的所見とくに核の大きさ，円形性，均一性，核質および核小体の 状態を指標とした核型のみによる悪性度（grade）と予後につき検討した。

(1) stage 別の 5 年生存率は stage I一68.0\%, II-64.9\%, III-34.9\%, IV-6.2\%であり明らかに予 後と相関していた。しかし stage I と II には統計学的に有意差を認めなかった。

（2）細胞型，組織構築による分類では細胞型では紡鍾細胞の混在をみるものまた組織構築では肉腫様 の構築の混在をみるものは比較的少数ではあったが明らかに予後不良であった。一方他の細胞型, 組織 構築には予後との相関は認められなかった。

（3）grade 別の 5 年生存率は grade $1-80.4 \% ， 2-71.5 \% ， 3-33.1 \% ， 4-7.9 \%$ で stage と同様 に明らかな予後との相関を認めたが grade 1と 2 には有意差を認めず grade は low grade と high grade の 2 段階分類としても良いと思われた。

(4) stage と grade との組み合わせでみると low stage（I～II）では low grade 症例の占める割合が 高くまた予後も良好であったが high grade 症例はやはり low stage といえども明らかに予後不良で あった。 また high stage (III〜IV) では逆に high gradeの占める割合が高く長期生存例はほとんどが low grade 症例であった。

（5）腎細胞癌の予後をある程度知る上で， stage と核型による grade との組み合わせで検討する事が 臨床的に有用であると考学られた。

\section{緒 言}

腎細胞癌は未だ予後の比較的不良な悪性腫瘍であり 諸家の報告では 5 年生存率は打拈よそ40～60\%であ $ろ^{1) \sim 7)}$.

現在宿主側因子を除く腫瘍側因子で予後の最も的確 な指標となるものは手術所見を中心とした臨床病期, 腫腸の進展度 (Stage) であると思われるが全て手術的 に摘除しえたと考えられる low stage 症例でも急速に 血行性転移をみる事や一方 high stage 症例でも進行 の比較的緩除な症例をしばしば経験する。この点，腎 細胞癌の病理組織学的悪性度 (grade) は未だ確立され て扣らず従来より細胞型，組織型，核異型を含めた腎 細胞癌の分化度を指標とした grade は主に腎細胞癌 の病理組織所見が極めて多彩である事により比較的再 現性に乏しく難解で一般的に検討されてはいなかった と思われる。一方本邦でも病理組織学的に腫瘍内血管 の腫瘍塞栓の有無 ${ }^{8)}$, 腫場と周囲組織との境界の鮮明 さ9)が検討されよく予後と相関する事が指摘されてい る.

分化度を指標とした悪性度として skimer ら²)は腎
細胞癌の核異型のみに注目した簡易で比較的的再現性 の高い gradeを検討しょく予後と相関する事を指摘 した. 今回我々も核型による gradeを中心に腎細胞癌 の病理組織学的所見と予後につき検討したので報告す る.

\section{対象と方法}

1969年から1982年をでの 14 年間に北海道大学付属病 院及び関連病院で診断された腎細胞癌症例は159例で らち追跡不能例を除く153例を対象とした。

内訳は男子 110 , 女子 43 例 $(2.7: 1)$ で年齢は 20 歳 から79歳まで平均56歳であった。患側は右側78例, 左 側75例，両側性 1 例である.

各症例の stage は現在最も広く用いられている Robson $^{10)}$ の stage により分類し, stage Iは腎被膜を 超えないもので75例, stage II は超觉るが腎周囲脂肪 組織内に限局するもので24例, stage III は腎静脈から 下大静脈にかけての腫瘍血栓もしくは局所リンパ節へ の転移をみたもので33例, stage IV は隣接臟器への浸 潤をたは遠隔転移の認めるもので22例であった (Table 1). 初診時すでに遠隔転移を認め, 原発巣摘除 
Table 1 Clinicopathological stage

\begin{tabular}{cc}
\hline I & $75(49 \%)$ \\
II & $24(16 \%)$ \\
III & $33(21 \%)$ \\
IV & $22(14 \%)$ \\
\hline
\end{tabular}

\# : Robson's stage

不能であった stage IVの11例と病理組織標本を充分 に検討しえなかった 8 例を除く135例に病理組織学的 検討を行った。

（1）細胞型 (cell type)

cell type は明調細胞 (clear cell)のみのものを clear cell type とし顆粒状細胞（granular cell）のみのもの を dark cell type としこれらが混在するものを mixed type とした.ささらに一部にでも紡錘型細胞（spindle cell）の混在をみたものは spindle cell type とし分類 した。

（2）組織構築 (structural pattern)

組織構築による分類はその主な patternにより solid, tubular, papillary として検討したがその混在は 極めて多彩でとくに solid patternを除いては混在を みない症例は少数でありその分類に困難を感じたがそ の際は主なる構築をもって判定した，分類不能例を mixed pattern としさらに配列の乱れが著明で肉腫様 の構築を一部にでも認めたものは sarcomatoid pattern として分類した.

（3）悪性度（grade）

当初, 我々は skinner らの gradeにより分類を試み

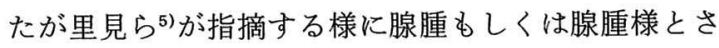
れる grade 1 の判断が困難であった事, また grade $2 \sim 3$ の分類において特に核の大きさの点で領界部分の 中間型が比較的多く存在する事等により以下の如く核 の大ささの指標として個々の症例の正常尿細管上皮細 胞核 (NTN : normal tubular nuclei) (Fig. 1) を用 い新たな 4 段階の grading system として検討した。

grade $1:$ 核はNTNよりやや小型で円形均一で核 質の濃縮をみとめ核小体をみとめない（Fig. 2)。

grade $2:$ NTN と同等かやや大きい核で円形で軽度 の形，大きさの不規則性をみ，核質はやや明るく核小 体も一部にみとめる (Fig. 3).

grade $3:$ NTN の拈およそ2 倍近くの大きさの核の 腫大をみ形，大きさの不規則性をみるが未だ円形は比 較的保たれている，核質は明るく空胞状が多いが時に 濃縮もみ明瞭な核小体を有する（Fig. 4).
Fig. 1 正常尿細管上皮細胞核 $(N T N) \times 400$

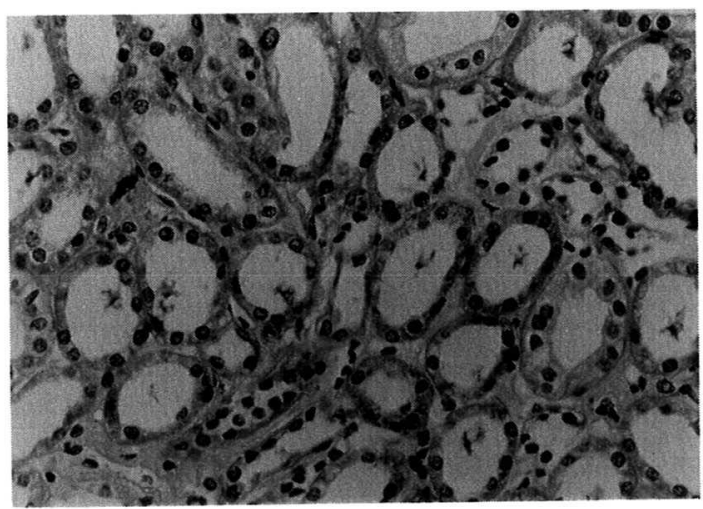

Fig. 2 grade 1: 核は TNT よりやや小型で円形, 均 一。核質は濃染し核小体はみとめられない。

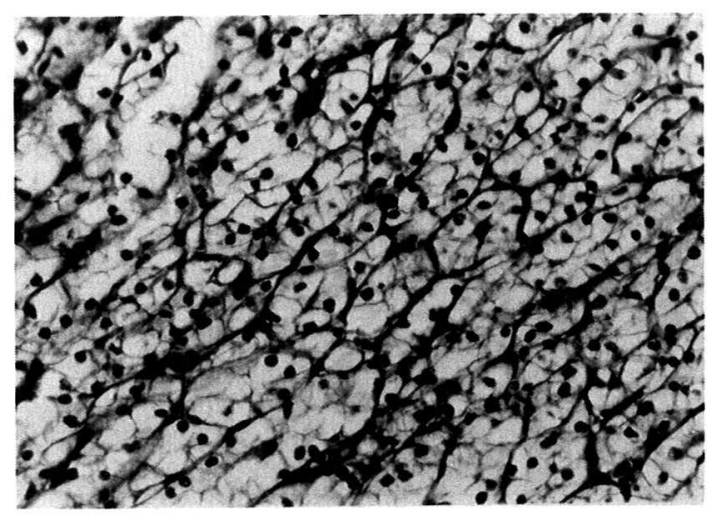

Fig. 3 grade 2:核はNTN とほぼ同じ大きさで円 形，軽度の不規則性をみる。核質はやや明るく核小 体もみとめられる。

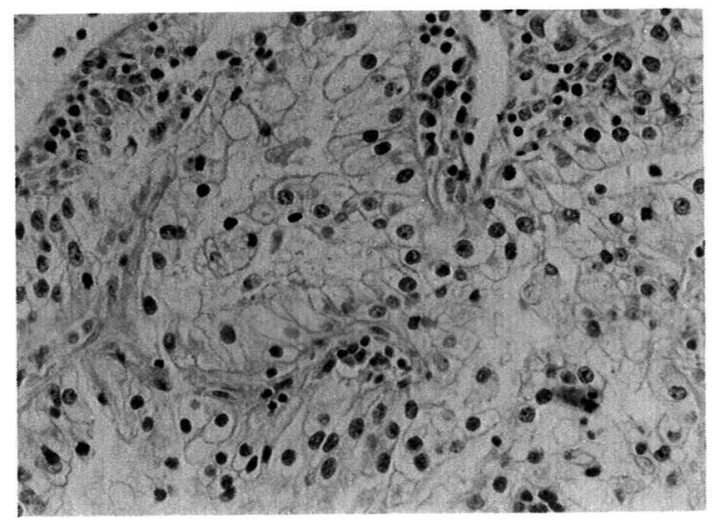

grade 4 : 非常に異型性に富む大型の不規則な核で 肥厚した核膜，異常な核質の淡明化，凝縮をみる(Fig. 
Fig. 4 grade 3：核はNTNのお捄よそ2 倍近くの 大ささで未だ円形は保たれるが不規則性をみる。核 質は明るく空胞状で明瞭な核小体をみる。

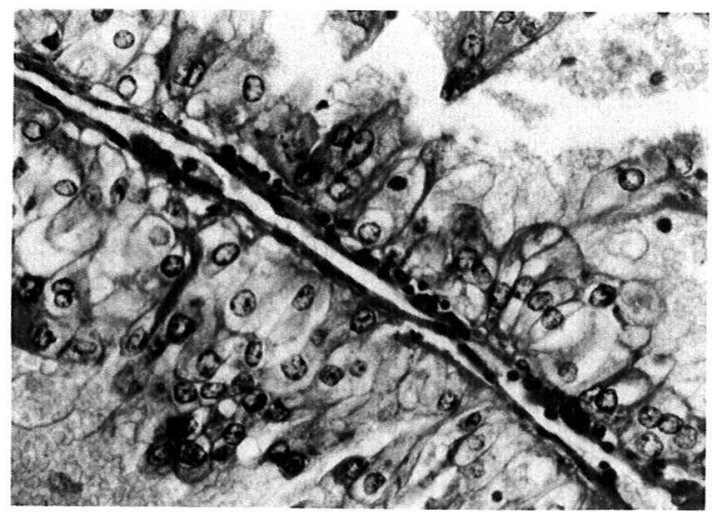

Fig. 5 grade 4: 巨大核をみとめ核質の異常が著明 で高度の不規則性をみる。（grade 1,2,3の核の混在 をみる)

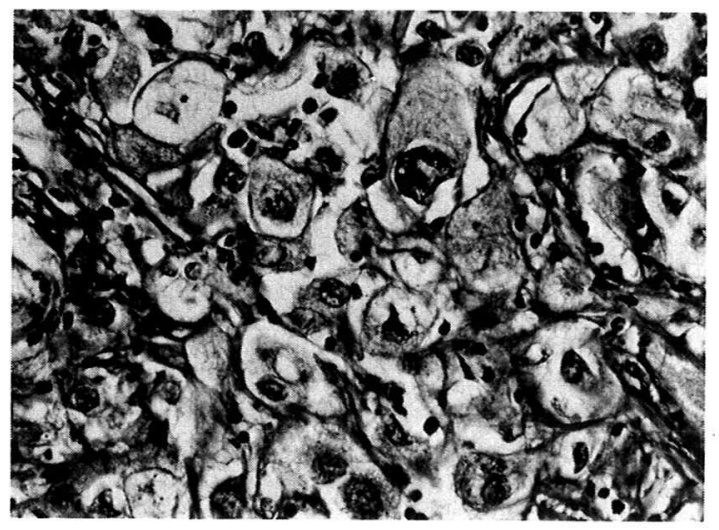

5)。また核質の異常は顕著ではないが円形を保ちえな い長円扁平な核も含まれる (Fig. 6).

各 gradeの混在は約半数以上の病理標本にみとめ られたが全て最も高い部分の grade で判定した。

\section{(4) 予後}

観察期間は最短 2 カ月, 最長 14 年で 1972 年以前の 10 年の観察可能症例は153例中20例のみで全体の生存算 出のみ10年生存率までとし他の各項目での生存率は今 回の検討では比較的短期の予後観察とし 5 年生存率ま でとした（10年以上の長期生存例は11例であるがうら 2 例は10年経過後転移が出現し死亡しており長期観察 の必要性が示唆されている).

全体の生存率のみ実測生存率で算出し, 各項目での 生存率は比較的少数例に有用とされる kaplan-Meier
Fig. 6 grade 4:核の大きさは中等度で核質の異常 も顕著ではないが核は円形を保ちえず偏平で不規則 性をみる. 紡鍾細胞型. (grade 2の核の混在をみる)

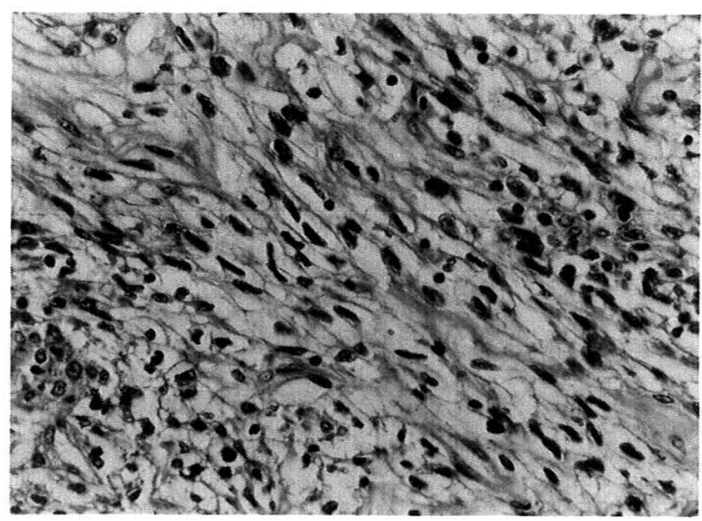

Table 2

\begin{tabular}{c|c|c|c|c|c}
\hline \multirow{2}{*}{} & \multicolumn{5}{|c}{ Years survival (\%) } \\
\cline { 2 - 6 } & 1 & 3 & 5 & 7 & 10 \\
\hline $\begin{array}{c}\text { Over all } \\
153 \text { cases }\end{array}$ & 80.0 & 58.4 & 50.7 & 43.4 & 38.6 \\
\hline
\end{tabular}

Fig. 7 stage \& survivals

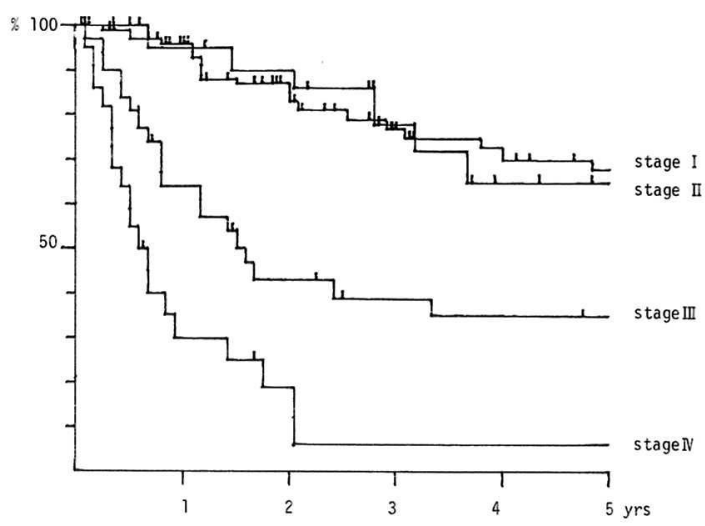

法 ${ }^{11}$ によった。検定はt-検定，一部 F-検定を用いた。

\section{成 績}

153例全体の生存率は 5 年生存率で $50.7 \%$ であり他 の報告に比し大きな差は認めなかった。10年生存率は $38.6 \%$ であった (Table 2).

各 stage での生存率曲線は (Fig. 7) で 5 年生存率で みると stage I-68.0\% (6.5\%-standard error), II$64.9 \%$ (11.9\%), III-34.9\% (9.1\%), IV-6.2\% (5.9\%) であり明らかに予後との相関がみられた。 
Table 3 Incidence of cell type and its relation to stage

\begin{tabular}{l|c|c}
\hline \multicolumn{1}{c|}{ cell type } & No. cases (\%) & $\%$ of low stage (I-II) \\
\hline clear cell & $62(45 \%)$ & $75 \%$ \\
dark cell & $23(18 \%)$ & $70 \%$ \\
mixed & $39(29 \%)$ & $68 \%$ \\
spindle cell & $11(8 \%)$ & $45 \%$ \\
\hline
\end{tabular}

本検討では stage I II に統計学的に有意差 $(p=$ 0.01）を認めずこれは恐らく比較的古い症例で周囲脂 肪組織への浸潤の有無につき充分に検討しえなかった 事も一因と考えられるが以下 stage I II を low stage としてまとめた。一方近年の根治的腎手術にもかかわ らず，腎静脈，周囲リンパ節への浸潤をみた stage III 症例は stage IV とは有意差をみとめるものの予後不 良であった。明らかな転移を有する stage IV 症例で最 長生存例は原発巣摘除が可能であった 66 歳男子で 6 年 生存したが肺転移により死亡している。

(1) cell type と予後

clear cell type は62例（45\%）で最も多く一方 dark cell type は23例（18\%）であり mixed type は39例 (29\%) であった。一部にでも spindle cell の混在をみ とめた spindle cell type は11例（8％）にみとめてい る。これら症例の stageをみると各々で low stage (I 〜II）の占める割合は clear cell-75\%, dark cell -70\%, mixed- $68 \%$ と統計学的に有意の差はみとめ なかったが spindele cell のみは $45 \%$ low gradeの 占める割合が有意に低值であった（Table 3).

生存率曲線でみると 5 年生存率では clear cell $-60.4 \%(\mathrm{~S} \cdot \mathrm{E}=7.1 \%)$, dark cell-55.1\% (11.5\%), mixed type-52.8\% (9.5\%) で mixed type がやや予 後不良と思われたがこれらでは統計学的に有意差 （p=0.01）をみとめなかった. しかし spindle cell type は49カ月迄の観察ではあるが明らかに予後不良であっ た (Fig. 8).

(2) structural pattern と予後

solid pattern が47例（35\%）と最も多く tubular pattern は34例(25\%), papillary pattern 19例(14\%), mixed pattern 21 例（16\%）で一部でも肉腫様変化の みられた sarcomatoid patternは14例（10\%）と予想 以上に多くみとめられた。 各々 stageでみると low stageの占める割合は solid-75\%, tubular-78\%, papillary-68\%, mixed一67\%でこれらに有意の差は みとめなかったが sarcomatoid pattern は $43 \%$ と有意
Fig. 8 cell type \& survivals

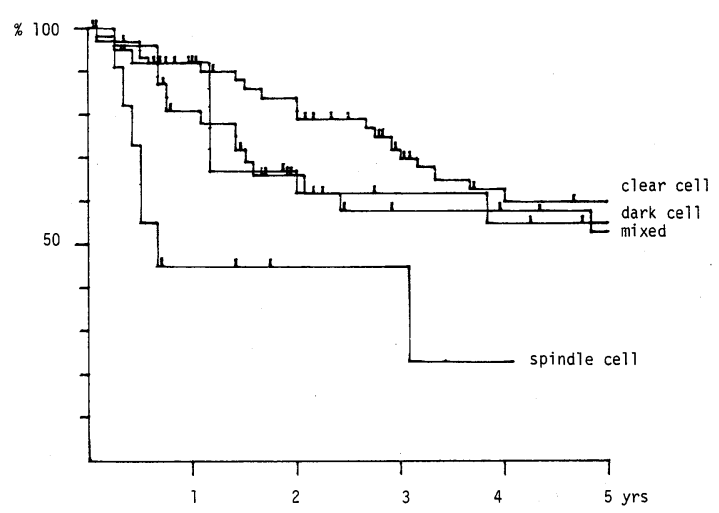

Fig. 9 structual pattern $\&$ survivals

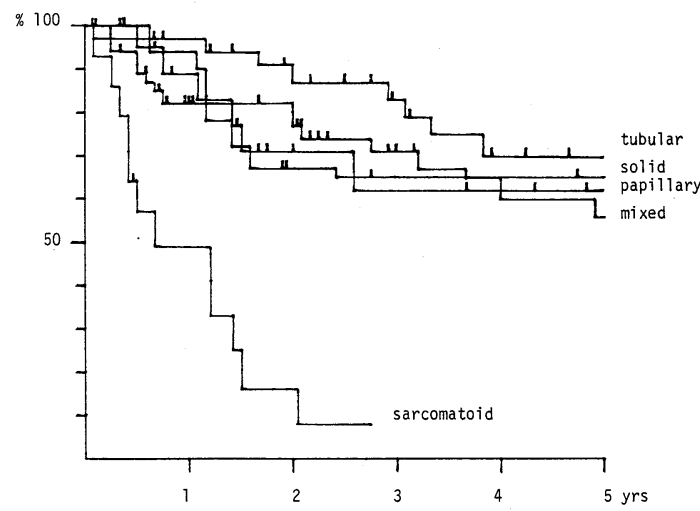

Table 4 Incidence of structural pattern and its relation to stage

\begin{tabular}{l|c|c}
\hline $\begin{array}{c}\text { structual } \\
\text { pattern }\end{array}$ & No. cases (\%) & $\%$ of low stage (I-II) \\
\hline solid pattern & $47(35 \%)$ & $75 \%$ \\
tubular & $34(25 \%)$ & $78 \%$ \\
papillary & $19(14 \%)$ & $68 \%$ \\
mixed & $21(16 \%)$ & $67 \%$ \\
sarcomatoid\# & $14(10 \%)$ & $43 \%$ \\
\hline \multicolumn{2}{c}{$\#$ if any }
\end{tabular}

\section{に低值であった（Table 4).}

生存率曲線で 5 年生存率は solid- $55.8 \%(\mathrm{~S} \cdot \mathrm{E}=$ $8.8 \%)$, tubular $-70.2 \%(9.0 \%)$, papillary $-60.0 \%$ (11.8\%), mixed-62.0\%(12.7\%)で tubular pattern が比較的予後良好であったが統計学的にはこれらに有 意差なく $(\mathrm{p}=0.01)$ 一方 sarcomatoid pattern は33力 月迄の観察ではあるが明らかに予後不良であった (Fig. 9). 
（3） grade と予後

各 grade の症例数は grade 1-20例 $(14.8 \%)$, grade $2-61$ 例 (45.2\%), grade 3-38例 (28.1\%), grade 4-16例 (11.9\%) で grade 2が最も多く次いで grade 3でこれらが70\%以上を占めた. 各 grade で low stage 症例が占める割合は grade 1-80\%, 2-77\%, 3-62\%，4-44\%で 1 と 2 には有意差をみとめないが low grade $(1,2)$ 症例は low stage の傾向にあった. 一方 high stage (III〜IV) はとくに stage IV の約半 数が grade 不明である為正確ではないが high stage 症例ではやはり high grade ( $3 \sim 4)$ が多い傾向にあ る (Table 5).

各 grade の生存率曲線をみると 5 年生存率で grade $1-80.4 \%(\mathrm{~S} \cdot \mathrm{E}=10.4 \%)$, grade $2-71.5 \%(6.6 \%)$, grade $3-33.1 \%$ (9.9\%), grade $4-7.9 \%$ (7.6\%) で明らかに予後との相関をみている。しかし 1 と 2 に は統計学的に有意差を認めず $(\mathrm{p}=0.01)$ 結果的には予 後良好な low grade (1２), 不良な high grade (3〜4) の 2 段階もしくは 3 段階 $(1 \sim 2 ， 3,4)$ 分類として もよいと思われた（Fig. 10).
以上ょり予後と明らかに相関するものとして stage と gradeがあると思われた (spindle cell type, sarcomatoid pattern は全て high grade $く に$ grade 4 であった)。そこで stage と grade との組み合わせで まず low stage (I～II) で各 grade の生存率曲線を検 討した (Fig. 11)。 5 年生存率では grade 1-88.9\% $(\mathrm{S} \cdot \mathrm{E}=10.5 \%), 2-74.2 \%(7.3 \%), 3-48.5 \%$

Fig. 10 grade \& survivals

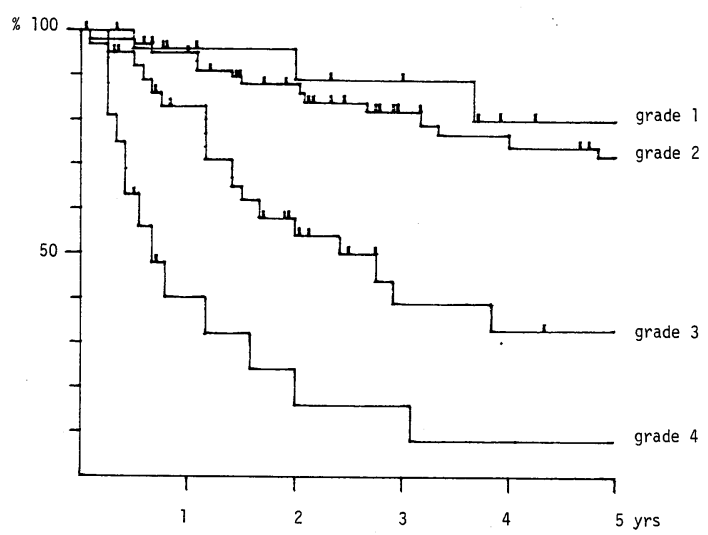

Table 5 Relationship between grade and stage

\begin{tabular}{r|r|r|r|r|r}
\hline & \multicolumn{4}{|c|}{ No. cases (\%) } & \multirow{2}{*}{$\%$ of low stage (I-II) } \\
\cline { 2 - 5 } & stage I & II & III & IV & \\
\hline grade 1 (20) & $11(55 \%)$ & $5(25 \%)$ & $2(10 \%)$ & $2(10 \%)$ & $80 \%$ \\
$2(61)$ & $40(66 \%)$ & $8(13 \%)$ & $10(16 \%)$ & $3(5 \%)$ & $77 \%$ \\
$3(38)$ & $15(39 \%)$ & $9(24 \%)$ & $10(26 \%)$ & $4(11 \%)$ & $62 \%$ \\
$4(16)$ & $5(31 \%)$ & $2(13 \%)$ & $7(43 \%)$ & $2(13 \%)$ & $44 \%$ \\
\hline 135 & \multicolumn{1}{|c|}{75} & 24 & 29 & 11 & \\
\hline
\end{tabular}

Fig. 11 grade \& survivals in low stage (I II)

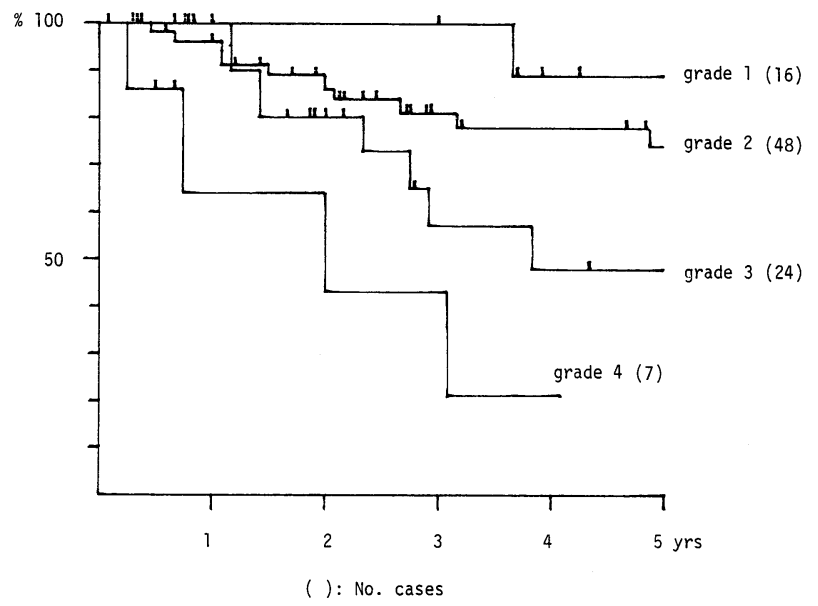


Fig. 12 grade \& survival years in high stage

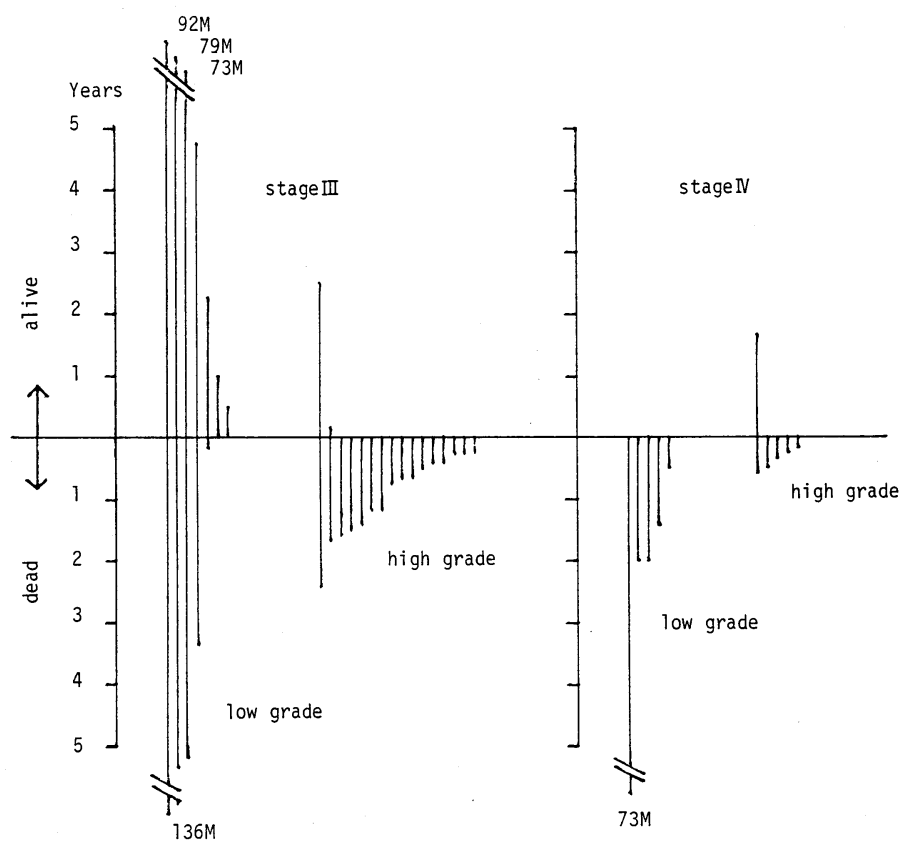

(13.5\%) で grade 4は最長生存が49カ月で21.4\% (18.8\%)でありやはり low stage と执いても予後との 強い相関をみとめた。手術的に医とんど摘除しえたと 予想される low stage 症例でも high grade (3〜4) の ものは予後不良であった. grade 1 2には統計学的に 有意差 $(\mathrm{p}=0.01)$ をみぬず grade のみの生存率で前 述した様にこれらは low grade とし，まとめてもよい と考觉られた。

一方 high stage 症例は全体の症例数が少ない事, ま た stage IV 症例の約半数が原発巣摘除不能であった 為充分に病理学的検討を施行できなかった事により正 確な評価はしえないが実際の生存期間でみると high stage に拉ける長期生存例は殆んど low grade 症例で あった (Fig. 12).

\section{考按}

腎細胞癌の病理組織学的悪性度 (grade) は未だ確立 されたものではなく high stage 症例はともかく手術 的にほぼ完全に摘出したと予想される low stage 症例 の予後を予測する事は困難であった。

従来より腎細胞癌の悪性度の検討は主に核異型, 細 胞型扣よび細胞構築による分化度の総合的判断を指標 としている(12)13)が腎細胞癌はこれら病理組織所見が 極めて多彩な腫瘍であり再現性の問題, 領界部分の判 断の困難さをみとめる事は否定しえず十分に一般的な
ものとは思われない。

一細胞型掞よび組織型と予後一

また細胞型のみまたは細胞構築のみの点から予後と の関連が種々報告されており細胞型では clear cell が 比較的予後良好で dark cell が予後不良とする報 告2)14115) や組織構築では papillary pattern が予後良好 とする報告16) るみるが逆に否定的な報告317718) もあり 予後との関連は明らかではないと思われる。しかし細 胞型では spindle cell の混在, また組織構築では肉腫 様部分の混在をみるものとは諸家の報告でもほぼ一致 して予後不良とされている(2)118) 20). 本検討にても細 胞型では clear cell と dark cell との間には 5 年生存 率に怙いては統計学的に有意差をみとめず, 一方少数 例ではあるが spindle cell の混在をみとめたものは明 らかに予後不良でまた組織構築においてもやや tubular patternが予後良好ではあったが各 pattern に 5 年生存率に扔いて差を認めずただ肉腫様の細胞構 築の混在をみたものは明らかに予後不良であった。

一核型による grade と予後一

1971年 skinner ら ${ }^{2)}$ は主に腫瘍細胞の核異型性のみ に注目し最も悪い部分で grading を行い多数例で検 討し比較的よく予後と相関する事, また stage との組 み合わせにより，より臨床的に有用である事を指摘し た。 その後主にこの核異型を中心とした grading が報 
告され予後とよく相関する事が指摘されてい

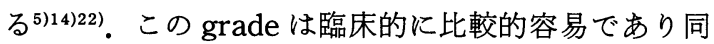
時に多数症例の検討が可能である事また再現性が比較 的良好であるという利点がある。

我々も当初 skinner らの grade により検討したが 前述した様に腺腫様とされる grade 1の核異型の記載 が充分でない事，また中間型の 2 と 3 の判定上特にそ の核の大ささの点で予想された以上に領界部分が存在 する事等により，(1) 核の大きさ，(2) 円形，均一性， （3）核質，核小体の状態により新たな核型による grade とし検討した。この核型による grade はまず 個々の stage とよく相関し low gradeは low stage, high grade は high stage の傾向にあり 5 年生存率で よく予後と相関していた.

確かに核の異型性（分化度の指標）はそれ自体でよ く予後と相関すると考兄られたが予後とよく相関する と思われた他の因子である stage との組み合わせでは 予想される程は明瞭な予後との相関性は指摘されてい

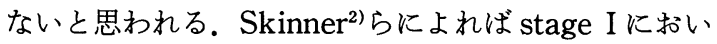
ては grade 1 2が比較的良好で grade 3〜4が不良で あるが stage 2では grade とは相関しない事, また里 見ら ${ }^{5}$ は stage I では各 grade の生存率に有意差をみ とめず skinner らと同様に stage III 症例に拈いての み各 grade に差がみられるとしている。我々の検討で は grade と stage の組み合わせはよく予後と相関し 特に gradeを low, high 92 段階とし更に stage I, II を low stage としまとめる事により，ょりょく予後と の相関がみとめられていた. low stage 症例でも high gradeのものはやはり予後不良であり high stageで も low gradeのものは進行が比較的緩除であると考 えられた。

以上核型による grade $は$ 予後とよく相関しとくに stage との組み合わせで臨床的に極めて有用であると 思われたがこの核型による grade は報告者により多 少の違いがあり25)14)17)，また一定程度主観性を認める 事は否定し党ない。しかし里見らも指摘する様に grade 1 が 3 や 4 と分類される様な事は考劣にくく比 較的再現性が豊富でありまた check point が限られて いる為に 1 症例につき多くの病理標本の検討が可能で （現在では我々は 1 症例につき最低でも 8 力所以上の 部分で検討している）最も悪い部分を見落す可能性も より少ないと思われ今後は本邦でも是非集学的に検討 されるべきものと考えられる。この点我々は核型によ る grade は low grade と high gradeの 2 分類法とし
て良いという印象であった。

以上の様に結果的には核型による悪性度は腎細胞癌 の予後を反映するものと思われたが，腫瘍細胞の分化 度を核型のみで判定する方法は一般に用いられる方法 ではなくまた病理学的にも根拠に乏しいものと考觉ら れる，最近著者らは細胞質の分化度を指標とした腎細 胞癌の基底膜特異蛋白 laminin 産生能を免疫組織化学 的に検討しある程度予後と相関する事を報告した ${ }^{21)}$ 今後これらの腎細胞癌の形態学的あるいは機能的な新 たな知見が加わる事により核型による悪性度以上に合 理的な分類がなされるものと考えられる。

最後に以上の検討により, 進行性腎細胞癌の積極的 治療は勿論であるがそれにもまして low stage の腎細 胞癌の治療, すなわち腫瘍摘出後の adjuvant 療法を いかにすすめるかが今後の大きな課題になると考兄ら れた。

\section{結 語}

1969年から1982年までの腎細胞癌153症例を対象と して臨床病期 (stage) 拈よび病理組織学的所見，とく に核型による悪性度 (grade) と予後との関連につき検 討した。

（1） stage は明らかに予後との相関をみたが stage I と II の間には有意差を認めなかった。

(2) 細胞型および組織構築では予後との相関は認め なかったが，細胞型では紡錘細胞の混在，組織構築で は肉腫様構築の混在をみたものは明らかに予後不良で あった。

（3）核型による grade も明らかに予後との相関を みたが grade 1と 2 では有意差を認めず, low grade $(1,2)$, high grade $(3,4)$ の 2 段階として分類しても よいと考えられた。

(4) stage と grade の組み合わせでみると low grade 症例は明らかに low stage (I〜II)の傾向にあり また high grade 症例はまた high stage（III〜IV) の 傾向にあった. low stage 症例でも high grade 症例は 明らかに予後不良でありまた high stage 症例で長期 生存例は殆んどが low grade 症例であった。

（5）腎細胞癌の予後を検討する上で核型による grade と stage の組み合わせで検討する事が臨床的に 有用であると思われた。

稿をとじるにあたり病理学的に多大な御指導, 御助言を いただいた北海道大学付属病院病理部安住典夫先生に深謝 すると共に御協力をいただいた教室諸兄に感謝いたしま す. 
（尚, 本論文の要旨は第21回日本癌治療学会総会にて報告 した.)

\section{文 献}

1) Arner, O., Blanck, C. and von Schreeb, T.: Renal adenocarcinoma: Morphology-grading of malignancy-prognosis : A study of 1977 cases. Acta Chir. Scand. Supple., 346, 23-32, 1965.

2) Skinner, D.G., Colvin, R.B., Vermillion, C.D., Pfister, R.C. and Leadbetter, W.F.: Diagnosis and management of renal cell carcinoma: A clinical and pathologic study of 309 cases. Cancer, 28, 1165-1177, 1971.

3) McNichols, D.W., Segura, J.W. and DeWeerd, J. H. : Renal cell carcinoma : Long-term survival and late recurrence. J. Urol., 126, 17-23, 1981.

4）䢐田壽彦：腎細胞癌の予後. 日泌尿会誌，72, 10-25, 1981.

5）里見佳昭，高井修道，近藤猪一郎，岩崎孝史，吉邑 貞夫, 福島修司, 古烟哲彦, 石塚栄一：腎細胞癌の stage 及び grade と予後. 日泌尿会誌，72， 278-287, 1981.

6）松田 稔, 長船匡男, 古武敏彦, 園田孝夫：腎細胞 癌の臨床的研究. 日泌尿会誌, 67, 635-645, 1976.

7）宮川美栄子, 吉田 修, 加藤篤二：腎癌に関する臨 床統計的観察一組織像と予後を中心として一。泌 尿紀要， 15，304-320，1969.

8) 斉藤 博, 加藤幹雄, 山内昭正, 石渡大介, 横川正 之, 青木 望, 高浜素秀: 腎腺癌の静脈内腫場栓塞 之遠隔転移。日泌尿会誌, 70, 1072-1077, 1979.

9）米田文男, 赤木 郷, 大塚 久: 腎細胞癌の臨床病 理学的検討一特に組織像と予後との関係について 一. 日泌尿会誌, 73，326-335， 1982.

10) Robson, C.J., Churchill, B.M. and Anderson, W. : The results of radical nephrectomy for renal cell carcinoma. J. Urol., 101, 297-301, 1969.

11) Kaplan, E.L. a d Meier, P.: Nonparamtric estimation from incomplete observations. Am, Stais. Ass. J., 53, 457-481, 1958.

12) Hand, J.R. and Broders, A.C.: Carcinoma of the kidney: The degree of malignancy in rela- tion to factors bearing on prognosis. J. Urol., 28, 199-216, 1932.

13) Riches, E.W., Griffiths, I.H. and Thackray, A. C.: New growths of the kidney and ureter. Brit. J. Urol., 23, 297-301, 1951.

14) Murphy, G.P. and Mostofi, F.K.: The significance of cytoplasmic granularity in the prognosis of renal cell carcinoma. J. Urol., 94, 48-54,, 1965.

15) Amtrup, F., Hansen, J.B. and Thybo, E.: Prognosis in renal carcinoma evaluated from histological criteria. Scand. J. Urol. Nephrol., 3, 198-202, 1974.

16) Mancilla-Jimenez, R., Stanley, R.J. and Blth, R. A. : Papillary renal cell carcinoma : A clinical, radiologic, and pathologic study of 34 cases. Cancer, 38, 2469-2480, 1976.

17) Boxer, R.J., Waisman, J., Lieber, M.M., Mampaso, F.M. and Skinner, D.G.: Renal carcinoma: Computer analysis of 96 patients treated by nephrectomy. J. Urol., 122, 598-601, 1979.

18) Fưhrman, S.A., Lasky, L.C. and Limas, C.: Prognostic signoficance of morphologic parameters in renal cell carcinoma. Am. J. Surg. Pathol., 6, 655-663, 1982.

19) Farrow, G.M., Harrison, E.G. Jr. ans Utzz, D.C. : Sarcomas and sarcomatoid and mixed malignant tumors of the kidney in adults-Part III. Cancer, 22, 556-563, 1968.

20) Waters W.B. and Richie, J.P.: Aggressive surgical approach to renal cell carcinoma: Review of 130 cases. J. Urol., 122, 306-309, 1979.

21）坂下茂夫, 中西正一郎, 出村孝義, 榊原尚行, 小柳 知彦: 腎癌から分離した基底膜抗原とその組織内 局在. 日泌尿会誌,

22) Syrjänen, K. and Hjelt, L.: Grading of human renal adenocarcinoma. Scand. J. Urol. Nephrol., $12,49-55,1978$.

（1984年 3 月 28 日受付） 